\title{
TOYO UNIVERSITY
}

Japanese Society and Culture

\section{An International Legal Consideration of the Issues on Lethal Autonomous Weapons Systems Including Nanomachine: A Perspective of International Law Studies in Japan}

Hiroshi Saito

Faculty of Law, Toyo University

Follow this and additional works at: https://gensoken.toyo.ac.jp/japanese-society-and-culture

Part of the International Law Commons, and the Military, War, and Peace Commons

\section{Recommended Citation}

Saito, Hiroshi (2021) "An International Legal Consideration of the Issues on Lethal Autonomous Weapons Systems Including Nanomachine: A Perspective of International Law Studies in Japan," Japanese Society and Culture: Vol. 3 , Article 4.

DOI: $10.52882 / 2434-1738-0304$

Available at: https://gensoken.toyo.ac.jp/japanese-society-and-culture/vol3/iss1/4

This Article is brought to you for free and open access by Institute of Social Sciences. It has been accepted for inclusion in Japanese Society and Culture by an authorized editor of Institute of Social Sciences. 


\title{
An International Legal Consideration of the Issues on Lethal Autonomous Weapons Systems Including Nanomachine: A Perspective of International Law Studies in Japan*
}

\author{
Hiroshi Saito **
}

Abstract

This paper aims to explore the legal issues on the use of Lethal Autonomous Weapons Systems (LAWS). This study is based on the recent research trend in Japan regarding studying the relationships between the international humanitarian law and the international law of human rights. The paper seeks to apply the integration theory to the relationship of both laws. As a result, this idea can pave the way for suppressing the usage of LAWS in future armed conflicts. Since the use of LAWS may lead to immense injury to fundamental human rights, it is necessary to adopt the integration theory to prevent futile, unnecessary and inhumane damage.

In addition, when considering the components of a nanomachine, the most important component is the autonomous non-metalic system of the machine. Although there are some international conventions that are aplicable to this system, some interpretive problems still exist. This situation shows that international law does not have to be divided into international human rights law and international humaniterian law. At the same time, strictly speaking, there is no international law that governs the nonmetallic system of a nanomachine at the present.

Keywords: LAWS, International Law, Responsibility and Liability, Armed Conflicts, Nanomachine

Preface

Legal issues on the use of Lethal Autonomous Weapons Systems (LAWS) have been long considered after studies on this topic begun. Such weapons are going to be realized today in the battle fields of international relations. Conversely, researches on weapons in the natural sciences in Japan have been avoided. This was due to the country's experiences in the World War 2, where scientific studies contributed to Japanese militarism and the war. Legal studies on the International Law of War were prohibited by the General Headquarters (GHQ) directly after the World War 2. Since then, the study of international law in Japan has been in a state of 'Unification of Peacetime'. Since Japan and its people would never go to war, it has been deemed unnecessary by scholars to research and study the international law of war or armed conflicts.

Although such an academic situation has not changed, the international relations of countries around Japan have been changing rapidly. For example, there have been numerous reports on terrorism cases,

※ The original version of this article was published on Kenpo Kenkyu No.24 by Kenpo Gakkai. This article has been corrected and new ideas have been added by the author.

※ Professor of Public International Law and Philosophy of Jurisprudence, Faculty of Law, Graduate School of Law, Toyo University, Tokyo. 
the new cold war between China and the USA, and socio-political and economic problems in North Korea, to name a few. Because of this, some researchers have already started with legal studies on the issues on LAWS, with the perspective of Japanese researchers on international law has been changing. These have included the law of international armed conflicts.

This essay aims to consider the legal issues on LAWS including nanomachines from the perspective of Japanese studies of international law. More specifically, this paper shall look into the derivative problems caused by the use of LAWS, on the basis of the relationship between the international law of human rights and the international humanitarian law.

\section{Three Types of International Legal Studies on LAWS}

There are three types of approaches in exploring the issues on LAWS: the philosophical approach; normative approach; and the interpretative approach.

The philosophical approach means the definition preceding type. In one instance, especially from a nano-level viewpoint, this approach may be used to look into the difference between humans and robots. This is the most important and thoughtful approach, but it takes up so much time before arriving at a conclusion. Hence, this is not realistic and practical.

The normative approach means regulative preceding type. Many international congresses or meetings among governments use this approach. The intergovernmental congress on The United Nations Convention on Certain Conventional Weapons (CCW) plays a central role in this issue. The third informal congress of experts ${ }^{1}$ suggested ideas to establish the governmental expert congress. They also shared opinions on technical developments in the civil fields not being disturbed by the regulation of LAWS. Furthermore, they talked about the importance of applying the international humanitarian laws, the significance of a legal examination system on weapons, and how these may significantly affect human rights or human dignity. The normative approach is characterized by restricting the future use of LAWS. On the other hand, that no state would use the perfect LAWS similar to how these are usually used in scientific fiction movies is the common understanding in the aforementioned conferences. Hence, every state must reach a consensus in restricting the developments of LAWS. This is particularly true especially for those states being tried before the United Nations. However, there is a concern over which the reaching of consensus or development weapons is completed faster. Such concern leads to doubt on the possibility of achieving an international agreement. One of the causes of such is ambiguity in the regulation of norms and targets relating to the definition of LAWS.

The interpretative approach is the most realistic one at present. Many researchers are putting forward doctrines or theories on the interpretation of treaties related to LAWS2. There are opinions based on the interpretations limited to the present international rules. There are also those which were considered from responsibility-based analogies of existing equipment. Furthermore, future expectations were also taken into consideration. One of the researchers, for example, compared LAWS with boy soldiers by exploring their responsibilities and found them to be very similar ${ }^{3}$. The researcher argues

\footnotetext{
1 Ministry of Foreign Affairs of Japan, <http://www.mofa.go.jp/mofaj/dns/ca/page24_000593.html> access 17:31, 5th Dec. 2017,< http://www.mofa.go.jp/mofaj/gaiko/arms/ccw/index.html> access 17:41, 5th Dec. 2017. Cf., "Report of the 2016 Informal Meeting of Experts on Lethal Autonomous Weapons Systems (LAWS)", 2016 CCW meeting of experts on autonomous weapons,

$<$ http://www.researchingcriticalwill.org/disarmament-fora/ccw/2016/laws>

2 Cf., N. Bhuta, S. Beck, R. Geiss, H. Y. Liu and C. Kress, Autonomous Weapons System: Law, Ethics,

Policy, 2016. Cambridge Univ. Press, pp.39-40.

3 Ibid., pp.40-42.
} 
that the one who does not have the responsibility should not be thrown into the battlefield. Similarly, the use of LAWS in the battlefield is illegal, in accordance with Article 77 and Article 4 of Protocols 1 and 2 of the Geneva Convention. Furthermore, this is also against Article 8 of the Statute of the International Criminal Court. However, it can be questioned whether it is possible to equate LAWS with boy soldiers. There are also some analogies based on autopilot systems of aircrafts, and the responsibilities on the process of design, manufacture, programmes, and actual battle. There has been an opinion that LAWS have the same process as that of the said autopilot system, with legal responsibilities in each part of the process. It may be very difficult, however, to establish an accident investigation committee which can analyse each part of the problem to discover its causes. This is because LAWS is the accumulation of intellectual properties, and most of them are military secrets. Other opinions use the regulations of weak protection 4 (i.e., children, women, or civilians) on the international humanitarian law, where it is illegal to attack these 'weak' members of the society without correct recognition and distinction. In other words, in this opinion LAWS do not have the ability to pave the way for such acts.

On the basis of these previous researches ${ }^{5}$, this essay considers the issues of LAWS through an interpretative approach as a premise of discussions in the International Court of Justice ${ }^{6}$. It is important to take note, however, that many researchers in the world could not understand the Japanese papers used in this essay since most of these papers have been published in Japanese.

\section{Criminal Liability concerning LAWS}

Firstly, in consideration of the issues of LAWS, they may be seen as battle machines used by humans in armed conflicts, even though it is autonomous? ${ }^{7}$. The robot, which is entirely autonomous like those films, will not be realized just yet. At the present, most of the researchers are expecting that such a robot will not be used until the legal and technical issues are already solved. In other words, LAWS become autonomous when they are used as a battle machine. On the basis of such a point, the idea which equated LAWS with boy soldiers is rejected. Therefore, the responsibility of using LAWS is not at present supposed as an issue of international law.

(1) When international law is applied on the issue of LAWS as a new battle machine, three problems arise: the lack of a law; the legality of the new weapon; and the way to use it ${ }^{8}$.

First of all, the lack of law is a problem of applicable rules or articles to new weapons. In most theories or opinions, the Martens clause is the general rule. It is possible on the basis of precedents and theories on Article 38 of the International Court of Justice (ICJ) to apply this clause to concrete incidents. ${ }^{9}$ However, it needs a certain period to converge.

The second problem is on the legality of the new weapons. According to Article 36 of the Protocols

\footnotetext{
4 This opinion is based on the regulations of international humanitarian laws.

5 The followings are major researchers in Japan. They published some academic articles about LAWS on journals in Japanese, which are referred here. Kengo IWAMOTO, Yasuhito FUKUI, Fumio SHINPO, Ayahito KAWAGUCHI, etc. 6 From viewpoint of the relations between the international law and the domestic law, the legal integrity would be an important issue, but this isn't treated in this essay this time.

7 Cf., <https://wireless.jp/2016/02/50129> access 14:11, 11th Dec. 2017.

8 Those three issues are also presented by researchers in footnote 3 .

9 Martens clause means the preamble of Convention respecting the Laws and Customs of War on Land, 1910 into force, and other legal principles, international customary law or precedents for the humanitarian rules and public consciences.
} 
Additional to the Geneva Convention dated on 12 August 1949, relating to the Protection of Victims of International Armed conflicts (Protocol 1):

"In the study, development, acquisition or adoption of a new weapon, means or method of warfare, a High Contracting Party is under an obligation to determine whether its employment would, in some or all circumstances, be prohibited by this Protocol or by any other rule of international law applicable to the High Contracting Party."

By applying this provision to the problem of the legality of new weapons, LAWS then being considered as 'new weapons' should be judged so that careless usage of it will be suppressed. However, there is still doubt with regard to its effectiveness. This is due to the fact that the state or government is the implementing entity which develops and uses the new weapons.

The third issue is on the proper way to use the new weapons. Article 48 of Protocol 1 of Geneva Conventions determines the principle of distinction. Furthermore, the first paragraph of the Article 51 determines the estimation of a civilian. Section $b$ of the fifth paragraph of this Article explains the protection of residents as civilians, while the fourth paragraph of the same article provides for the prohibition principle of indiscriminate weapons. Furthermore, the second paragraph of the article 57 states that precautionary measures are provided so that they shall prevent deviation on the way of usage on weapons in the battlefields. Using these new weapons shall be deemed legal, as long as the people using them are obeying the abovementioned rules. In case of people deviating from provisions providing for prohibitions in using LAWS, it is the person disobeying who has the responsibility.

(2) The illegal actions by soldiers against the international humanitarian law or the international law of armed conflicts are divided into two cases. The first is the case of practice by superior order, while the second is the case of practice by the personal decision of the soldier. With regard to the first case, the Rome Statute of the International Criminal Court (ICC Statute) provides in the first paragraph of the Article 33:

"The fact that a crime within the jurisdiction of the Court has been committed by a person pursuant to an order of a Government or of a superior, whether military or civilian, shall not relieve that person of criminal responsibility unless."

In this way: (a) the person concerned has a legal obligation to obey the orders by a superior or the government; (b) the person concerned did not know or understand that the order was illegal; and (c) the order was not expressly illegal but legal conditions were provided in the ICC Statute. This provision presupposes that a soldier is human. However, this may also be applied to LAWS, on the condition that: (a) obedience to the order of a superior is already secured before the legal implementation, because the program for running orders must be incorporated before LAWS is used in battlefields; (b) the interpretation on 'do not know' could become an issue. Considering it together with condition (a), the problem is not the answer of a 'do not know', but the presence of a program by which illegal action would be set. This is because the actions of LAWS rely on the decisions of artificial intelligence which are based on the first programmes. There is also a third condition: (c) a problem is also related to the program for 
the order by the superior.

Similarly, when the aforementioned provision applies to LAWS, the responsibility belongs to a government or a decision maker who decides to use LAWS in the battlefields. The government or a decision maker has a right or title to decide the contents of the program. However, it is important to note that because LAWS is not a real human but a weapon, it is impossible to apply the provision to LAWS.

In the second case, in relation to the first case, if LAWS is used in the battlefield under the command of a superior, we should consider Article 28 of the ICC Statute wherein 'the Responsibility of commanders and other superiors' is prescribed:

“(a) A military commander or person effectively acting as a military commander shall be criminally responsible for crimes within the jurisdiction of the Court committed by forces under his or her effective command and control, or effective authority and control as the case may be, as a result of his or her failure to exercise control properly over such forces, where: (i) That military commander or person either knew or, owing to the circumstances at the time, should have known that the forces were committing or about to commit such crimes; and (ii) That military commander or person failed to take all necessary and reasonable measures within his or her power to prevent or repress their commission or to submit the matter to the competent authorities for investigation and prosecution. (b) With respect to superior and subordinate relationships not described in paragraph (a), a superior shall be criminally responsible for crimes within the jurisdiction of the Court committed by subordinates under his or her effective authority and control, as a result of his or her failure to exercise control properly over such subordinates, where: (i) The superior either knew, or consciously disregarded information which clearly indicated, that the subordinates were committing or about to commit such crimes; (ii) The crimes concerned activities that were within the effective responsibility and control of the superior; and (iii) The superior failed to take all necessary and reasonable measures within his or her power to prevent or repress their commission or to submit the matter to the competent authorities for investigation and prosecution.”

This provision presupposes a human soldier. However, considering that LAWS is used under the commands of a superior, in the case of illegal acts through the use of LAWS under the Article 5 (crime of genocide, crimes against humanity, war crimes and crimes of aggression) ${ }^{10}$ of the ICC Statute, it is interpreted that the superior who commands its usage has the responsibility.

(3) In this way, when LAWS is used, a human who uses or commands its use does not control it directly. Therefore, it is impossible to impose the responsibility to LAWS itself. One can then interpret that the criminal responsibility based on the acts of LAWS belongs to the superior, commander or the government.

10 Each crime has detailed provisions in the article 6 (crime of genocide), the article 7 (crimes against humanity), the article 8 (war crimes) and the article 8 (2) (crime of aggression) in the ICC Statute. 


\section{Civil Liability concerning LAWS}

There is civil liability according to the illegal acts or torts caused by the use of LAWS in armed conflicts. This takes the form of compensation for damages. This issue is related to the sovereign immunity in the study of international law.

(1) The sovereign immunity is described as the jurisdictional immunity of states and their property. Such is also known as state immunity ${ }^{11}$. In the international society, each state has an equal title and right, and every state is equal under the law. As the result, a state and its properties does not need to be subject to the jurisdiction of other states. Traditionally, the general principle pertains to complete immunity; however, restrictive immunity has been rising recently. The principle of restrictive immunity divides acta jure imperii and acta jure gestionis - the immunity is admitted in the former case. There are two criteria for classification: the theory of the purpose of the action, and the behavioural standards theory. The latter gives priority to the character of its actions while the former is an idea to give importance to its purpose. At the present, both theories are opposing one another.

(2) In actual court cases, the court has applied the principle of complete immunity quite frequently. In the 2002 Yokota Air Base Case ${ }^{12}$, the Supreme Court of Japan decided that the Agreement under Article VI of the Treaty of Mutual Cooperation and Security between Japan and the United States of America, regarding Facilities and Areas and the Status of United States Armed Force in Japan (Japan-U.S. Status-of-Forces Agreement) exempts U.S. soldiers from compensation for damages by the tortious acts committed by them. This is because they were performing their official businesses. There was, however, the suggestion for the possibility of the restrictive immunity in its decision.

There was also a court case concerning compensation for damage in armed conflicts. This was the case of the Chinese Comfort Women. The Supreme Court of Japan rejected the arguments of the appellants in its decision. A state has a prerogative to treat and claim rights, including the rights of the individual based on the state's sovereignty. Furthermore, they have the right to 'renounce'. The San Francisco Peace Treaty includes the private rights of individuals in states concerned ${ }^{13}$. On the interpretation of 'a people's claim right renounced', it is discussed that the opinion of the Japanese government has changed from the theory of renunciation of diplomatic protection to the theory of renunciation of a procedural right. In other Japanese domestic court cases, there were two arguments. The first is that a state does not have a right and title to renounce the claim rights of individuals. They also cannot deny exercising those rights. The second argument is the theory of substantial renounce or the theory of waiver. The case of the Chinese Comfort Women suggested that to 'renounce' does not mean the lapse of claim rights. It is a function of the appeal rights based on the lost claim rights. This is a new opinion left from traditional opinions, which suggested that it is almost similar to the theory of renunciation of a procedural right ${ }^{14}$.

11 Cf., Kokusaihou Gakkai, Kokusai Kankei Hou Jiten, Sansei-Do, 2005, pp.456-457.

12 Case No., Heisei 11 (O) 887, Minshu, no.4, vol.56, p. 729.

13 Case, No., Heisei 17 (Ju) 1735.

14 There are many researches in Japan. In them the most concise and clear is the results published by Shuichi FURUYA, Kokusaihou Hanrei Hyakusen, ver.2nd, To-shin Dou, 2008, p.235. Other results are published by Ming HE, Bunkyo Daigaku Kokusai Gakubu Kiyou, No. 1, Vo. 17, 2006, pp.45-60. and Katsumi MATSUMOTO, Ritsumeikan Hougaku, no.292, 2003, pp.317-382. 
In the case of Greek Citizens vs. Germany in $2003^{15}$, a case concerning compensation related to the acts of German soldiers in the World War 2, the Greek district court ruled that Germany did not have a sovereign immunity. This is due to the fact that a restrictive immunity usually should be applied, but the violation of Article 46 of the regulations of the attached Convention regarding Laws and Customs of War on Land meant the violation of jus cogens. In this case it is considered a renunciation of state immunity 16 . The Greek Supreme Court ruled similarly in its decision. The Greek Special Supreme Court however kept the original decision which accepted state immunity. This Court showed that in view of decisions of the ICJ and of other countries, the international rule, which approves lawsuits on all of compensation due to torts done by soldiers of the accused country in foreign states, does not yet exist ${ }^{17}$. The plaintiff of such case, after the decision of the Greek district court, sued in the German court. The German Federal Supreme Court ruled that a state does not need to accept state immunity in the legal proceedings on acta jure gestionis of foreign states. However, a state has a right to claim a state immunity from the legal jurisdiction of another state in cases of acta jure imperii ${ }^{18}$.

Furthermore, in the case of Jurisdictional Immunities of the State in $2012^{19}$, a case which originated from the case of Ferrini for the compensation in the Italian court ${ }^{20}$, the ICJ arrived at a conclusion that the customary international law demanded to accept state immunity if foreign soldiers caused damages in the territory of other foreign states during the time of the armed conflicts ${ }^{21}$. It is pointed out, however, that the legal reason not to apply the rule of immunity for torts to military acts was not clear. It was added that the opposite opinion which argued not to be able to understand to give the wide-ranging immunity to the armed forces of hostile country 22 .

(3) It is understood that for situations mentioned above, although the principle of restrictive immunity is expanding in relation to compensation based on the military actions during armed conflicts, the principle of complete immunity is still used mainly in the decisions of courts. This is because it is very difficult to distinguish acta jure imperii from acta jure gestionis in cases of military acts involving the use of LAWS during armed conflicts. Such difficulty continues even after the said armed conflicts. It is probably difficult to understand and judge whether it is the acts done in connection with the LAWS which caused the criminal liability when acta jure gestionis is done through the use of LAWS. Conversely, there shall be no civil responsibility because such responsibility is not recognized as the acta jure imperii. Therefore, the state immunity would be responsible for the damages.

15 Cf., Greek Citizens v. Germany, 26 th June 2003, International Law Reports, vo. 129, p.556.

16 Haruyuki YAMATE, Kyoto Gakuen Hougaku, no. 2 and no. 3, 2005, pp.57-72, and ibid., no.3, 2006, pp.47-107.

17 YAMATE, ibid., no.2, pp.68-69.

18 YAMATE, ibid., no.3, p.51. This is the same as the translation of the decision of the German Federal Supreme Court.

19 Germany v. Italy: Greece intervening, <http://www.icj-cij.org/en/case/143/143-20120203-JUD-01-00- EN.pdf> 61.p. access 13:04, $11^{\text {th }}$ Dec. 2017.

20 Cf., <https://www.asser.nl/upload/docments/DomCLIC/Docs/NLP/Italy/Ferrrini_Cassazione_6-11- 2003.pdf> 10.p. access $17: 46.5^{\text {th }}$ May 2020.

21 Tomonori MIZUSHIMA, Shuken Menjo no Kokusaihou, Nagoya Univ., Press, 2012, p.157.

22 Ibid., p.159. Mikio MATSUDA, Kokusai Shihou Saibansho Hanketsu to Iken, vol. 4, Kokusai Sho-in, 2016, pp.457462 . 


\section{Essay from perspective of Result Responsibility}

(1) Taking into consideration the issues of LAWS on the conditions to be discussed in the ICJ and in legal hermeneutics, we were able to gather our results. LAWS as a new weapon could evade the lack of law. LAWS does not need to specifically exist in the character as being autonomous if it is autonomous and not controlled by humans. Depending on the ways of using the weapon concerned, criminal liability or civil responsibility or both may occur. On criminal liability, in the case that the use of LAWS causes the illegal acts against the Geneva Additional Protocol 1, the commander or superior who commanded to use the LAWS during the armed conflict has the liability based on the ICC Statute. On civil responsibility, if the damage occurs by the use of LAWS, all acts concerning LAWS are recognised as the acta jure imperii at the time of the armed conflicts. Hence, the principle of complete immunity is applied to such damage in accordance with judicial precedents, and the responsibility of compensation is evaded.

(2) However, assuming that there is an international armed conflict in the future, we should consider not only the relationship between right and duty but also other important issues as well. These include the problems on human rights and human dignity. In these issues, the urgent problem is the protection of victims who are refugees damaged by international and internal armed conflicts ${ }^{23}$. The victims in this case are the people who are compelled to take refuge in other countries because their social systems or places of living were destroyed by armed conflicts. These people cannot lead their own social lives and are being driven into very poor surroundings.

With regard to the support of the victims, the actual practice precedes the norms - such norms or rules have been formed based on those practices ${ }^{24}$. That the organization of humanitarian supports have pressured the governments or states to form new rules after the victims who were not protected by the existing rules were given aid and after the crises were converged is the fact behind this 25 . Being based on those researches, the rules or norms have been prepared. However, it is possible to produce a certain legal theory before the practices of LAWS, if we can presuppose the enlightening nature of international law.

(3) It is important to generalize the theory of restrictive immunity in relation with state immunity in the case of civil responsibility, and the theory to unify the international humanitarian law and the international law of human rights 26 . Three theories arise when we limit the relationship between the international humanitarian law and the international law of human rights: the separate theory; the complementary theory; and the integration theory. The first theory means that each legal system is independent. The second means that there is an interaction between two legal systems even though both systems are different. The third theory means that two legal systems exist in integration theoretically. In the advisory opinion of the ICJ in the 2004 case of the Construction of a Wall in the Occupied Palestinian Territory, it is suggested that there are three legal situations to which the international humanitarian

23 Tomoya UENO, Senso to Jindo Shien: Senso no Hisai wo Meguru Jindo no Seiji, Tohoku Univ., Press, 2012, pp.27-

29. In this academic book, the author analyses the issue on refugees and wandering people in detail.

24 Ibid., p.121.

25 Ibid., p.122.

26 On the criminal liability, as suggesting in the first half of this article, the liability belongs to a certain person by the rules of the existing international law. On the civil responsibility, however, since the issue connects directly to budgets or funds to support victims, it should be treated in this essay. 
law and the international law of human rights would be related. These are: the rights which are issues of solely the international humanitarian law, the rights which are the issues of solely the international law of human rights, and the rights which are the issues of both laws. In the last case, the law of human rights as a general law, and the humanitarian law as a special law, should both be deliberated together 27 . The main point is that the ICJ showed the possibility of applying the treatises of human rights in the situations of armed conflicts or wars ${ }^{28}$. In the case of the Democratic Republic of the Congo v. Uganda at $2005^{29}$, the ICJ ruled that the duties of the occupation state include the respect of the rules on the international humanitarian law and the international law of human rights, the protection of inhabitants from violence in an occupied place, and the special duty not to approve such violence by a third party ${ }^{30}$. Considering this case, we find the application of both laws during armed conflicts. Further, we could understand that this is almost a similar idea to the integration theory.

Adding positive laws, such as treaties, in many decisions of the international courts and documents of the executing agencies, the application of the international law of human rights during armed conflicts is accepted. As a result, 'the substantive parallelism' has been established in the sphere wherein some matters of both international laws are applied. A normative framework is constructed by the fusion of the two laws. Such is justified theoretically by the human rights norms whose nature is considered as jus cogens, and by the 'intransgressible principles of humanitarian law'. This strange expression is made by the ICJ, and it means that if a state violates these principles, the legal effect provided in Article 41 of the Draft Articles on Responsibility of States for Internationally Wrongful Acts in 2001 by the U.N. International Law Commission shall occur. ${ }^{31}$ The principle of interpretation provided in Section c of Paragraph 3 of Article 31 of the Vienna Convention on the Law of Treaties is seen as the method of putting in order the complicated relationships between those two laws. The article concerned provides that: "There shall be taken into account, together with the context: (c) any relevant rules of international law applicable in the relations between the parties." Treaties should be interpreted by the context and the relevant rules of international law. This means that the integration issue among treaties is related closely to the interpretation of treaties and the process of legal reasoning. Such a way of interpretation could contribute in furthering the underlying value in the international society. It is possible to recognize that the provisions of the Vienna Convention on Treaties embody the principle of 'systematic integration'. Treatises should be interpreted as referring to all principles and related rules of the international law, because there is a premise that the international law must be recognized as 'one legal system'. As such, 'the rules related to the international law' have to be considered when we interpret treaties, and the rules or norms of the customary international law which are compatible with treatises are included

27 Legal Consequences of the Construction of a Wall in the Occupied Palestinian Territory, Advisory Opinion of 9 July 2004, <http://www.icj-cij.org/files/case-related/131/131-20040709-ADV-01-00-EN.pdf> access 01:07, 13th Dec. 2017, p.46, pp.48-49.

28 Cf., Kouji TERAYA, "Kokusai Jindou Hou to Kokusai Jinken Hou tono Kankei, Senryo-chi ni okeru Hou”, Kokusai Hou Hanrei Hyakusen, ver. $2^{\text {nd }}$, No. 204, pp.222-223. Hisa-kazu FUJITA, "Paresuchina Senryo-chi ni okeru Kabe Kouchiku no Hou teki Kouka”, Hanrei Kokusai Hou, ver. $2^{\text {nd }}$, To-shin Dou, 2010, pp. 630-635

29 Case concerning Armed Activities on the Territory of the Congo (Democratic Republic of the Congo v. Uganda), Judgement of 19 December 2005, <http://www.cij-cij.org/files/case-related/116/116-20051219-JUD-01-00-EN.pdf> access $01: 25$, 13th Dec. 2017, 119 p.

30 Cf., Kazuhiko HIGUCHI, "Senryou Koku no Ryaku-datsu Kinshi”, Kokusai Hou Hanrei Hyakusen, ver. $2^{\text {nd }}$, No. 204, p. 229. Tsuneo YAMAMURA, "Kongo Ryouiki ni okeru Gunji Katsudou Jiken”, YOKOTA et al, ed., Kokusai Shihou Saibansho Hanketsu to Iken, vol. 4, pp. 55-56.

31 Minoru ARAI, “Kokusai Jinken Hou to Kokusai Jindou Hou no Kousaku: Jikkou teki na Secchuu- shugi”, Nihon Kokusai-Mondai Kenkyuu-Jo, Kokusai Mondai, no. 592, June 2010, p.16.å 
naturally in 'the related rules'. There is a case that the contents of customary international law include the international humanitarian law and the international law of human rights, and also that parts of customary law are same as the contents of treatises ${ }^{32}$. Further, the principle of 'more favourable provision granting greater protection ${ }^{33}$ ' applies the rules preferentially to protect an individual who has been victimized, even in the presence of the international humanitarian law or the international law of human rights. That principle is approved clearly in the Paragraph 8 of Article 75 in the Protocol 1 additional to the Geneva Conventions as following that: "No provision of this Article may be construed as limiting or infringing any other more favourable provision granting greater protection, under any applicable rule of international law, to persons covered by paragraph1." The second paragraph of the preamble of the Protocol 2, as a supplement to the Geneva Convention, prescribes as one of the grounds for that principle 'recalling furthermore that international instruments relating to human rights offer a basic protection to the human person'. As a result, there is the following opinion: generally speaking, when there are the military needs and the humane consideration in front of us, the influence of the international law of human rights toward the international humanitarian law trends to emphasize the humane consideration. The recent tendency wherein the international law of human rights penetrates the field of humanitarian law could solve the dispute on the relationship between the international law of human rights and the international humanitarian law ${ }^{34}$, although the field of rules on hostilities has been controlled by the international humanitarian law.

Based on international judicial decisions, recommendations and academic views, the integration theory is probably valid with respect to civil liability and compensation caused by the use of LAWS. The international society after World War 2 has been developing based on these two main ideal principles: the war illegalisation and the human rights guarantee. With respect to the international legal system, once the international law of peace becomes the general law, and the international law of armed conflicts is the special law, the idea that the law of humans is embedded in humanitarian law at the time of interpretation and application should be preceded as far as possible. This must be done in consideration of the legal system from the perspective of human dignity and guarantee of human rights, even though the principle of special law priority (specialia generalibus derogant, non generalia specialibus) ${ }^{35}$ exists. Such idea facilitates the guarantee of humane rights even during the armed conflicts.

(4) Assuming the integration theory, the idea of the 'result responsibility' is useful when we shift to the issue of the civil compensation. This is also called 'faultless liability' or 'risk liability'. For example, treaties relating to nuclear power provide the faultless liability of states and the focus is on the responsibility to supervisors. Moreover, the Convention on International Liability for Damage Caused by Space Objects provides the faultless liability for damages occurred on ground surface ${ }^{36}$. In the case of the Trail Smelter Arbitration (United States vs. Canada) ${ }^{37}$, the management responsibility of a state on territorial area

32 Ibid., p.19.

33 D. Schindler and J. Toman ed., The Laws of Armed Conflicts: A Collection of Conventions, Resolutions and Other Documents, Martinus Nijhoff, 1988, p. 667.

34 ARAI, op. cit., pp.21-23.

35 SHIBATA, HAYASHI and SASAKI ed., Raten-go Hou Kakugen Jiten, Jigakusha Pub, 2010, p. 279.

36 Cf., Kunihiko TATSUZAWA, Uchu Hou Sisutemu: Uchu Kaihatsu no tame no Hou Seido, Maruzen, 2000, pp. 240250.

37 “Trail smelter case (United State, Canada)” 16 April 1938 and 11 March 1941, Reports of International Arbitral Awards, <legal.un.org/raa/cases/vol_III/1905-1982.pdf> access 14:14, 13th Dec. 2017, pp. 1907-1982. 
usage was approved. The Arbitration Court ruled that a state had to take responsibility in case the damage accompanying serious consequences could be proved by obvious and persuasive evidence ${ }^{38}$. In the Alabama Arbitration, one of the important issues was whether or not the degree of considerable duty of caution to prevent legal infringement outside territory for foreign countries exists. On this issue, it was ruled by the court that the extent of considerable duty should be accurately proportional to the predictable risk. Furthermore, a certain treatment should be obligated regardless of realistic means of the United Kingdom ${ }^{39}$. The notable point of this decision is that the duty of caution is actually stricter than the precedential duty to process the similar problems in a domestic legal system ${ }^{40}$. This idea could be recognized as negligence, meaning that the liability or responsibility would not occur if the measures laid down in the criteria had been fulfilled. To impose the 'strict duty of caution' under circumstances in 1861 , however, is also interpreted as the creation of an opportunity towards risk responsibility ${ }^{41}$.

Risk responsibility still does not approve immunity in case of the existence of a factual causal relationship, although the risk responsibility has not yet been established, and its content does not prohibit dangerous acts. There are three types: the civil liability type; the mixed responsibility type; and the state-excusive responsibility type. The first means that the liability belongs to an operation manager; it is adopted in cases of aircraft damage or oil pollution damage. The second means that primarily an operation manager is liable, but when the burden of the responsible person is already excessive, the state which gave permission also bears part of the said burden. Such is adopted in the nuclear field. The third means that only a state takes responsibility. It is adopted in the space law field ${ }^{42}$. The fundamental idea of such is the seriousness and size of the scale on damages 43 .

In the case that immense damage occurs through the illegal acts caused by the use of LAWS, the civil liability or compensation belongs to a supervisor or a state. This is taking into account the principle of risk liability or result responsibility being embedded in the international humanitarian law. However, we still do not know how much degree of damage is considered as 'immense'. We also are unsure if there is actually an organization or a procedure to judge its existence. Generally speaking, those problems are going to be judged in the international court or the international special court being set up at the time of, or after, the armed conflicts. It is very hard to ensure its effectiveness since it may be impossible, in fact, to establish those international courts. Still, on the issues of LAWS, the possibility of somehow creating a mental or psychological suppression effect remains. This is possible if we have the abovementioned idea and decide to apply such rules and principles. At present, it is possible to believe in certain enlightening meaning in that trend, even though the only choice left is to do expectations ${ }^{44}$.

\footnotetext{
38 Ibid., p. 1965.

39 Taku KUMAGAI, "Terorizumu wo Keiki to suru Kokka no Kokusai Hou jou no Sekinin ni kansuru

Joron-teki Kousatsu”, Niigata Kokusai Joho Daigaku, Joho-Bunka-Gakubu Kiyou, no.11, 2003, p.25.

40 KUMAGAI, ibid., p. 25.

41 Soji YAMAMOTO, Kokusai Hou ni okeru Kiken Sekinin Shugi, Tokyo Daigaku Shuppan-kai, 1982, p. 115

42 Cf., YAMAMOTO, ibid. Atsuko KANEHARA, "Kiken Sekinin”, Kokusai Hou Gakkai, ed., Kokusai Hou Kankei Jiten, ver. $2^{\text {nd }}$, San-sei Do, 2005, pp.168-169. Naikaku Uchu Senryaku-shitsu, Uchu Katsudou Houan ni okeru Dai Sansha Songaibaishou Seido no arikata ni tsuite, 2015, pp. 1-10. <http://www8.cao.jp.go.jp/space/comittee/27housei-dai6/siryou1.pdf >. Sadao MOMIKI, "Kokka Sekinin to Koudo ni Kiken na Jigyou Katsudo” Chukyo Daigaku Hou Gakubu, ed., Chukyo Hou Gaku, nos. 2,3,4, vol. 23, 1988, pp.13-68. Kyo-ko HAMAKAWA, "Uchu Buttai ni yori Shuojita Songai ni kansuru Kokka Sekinin”, NDL., ed., Refarensu, March 2008, pp. 75-93. Many others.

43 TATSUZAWA, op. cit., p.249.

44 Cf., MIZUSHIMA, op., cit., p. 163.
} 


\section{Brief Summary}

Presupposing that the ICJ judges the issues of LAWS based on the existing international rules, there is high possibility of applying the immunity based on exemption from sovereignty. However, one may think about the present trend of restrictive immunity, and keep in mind the urgent problems caused by the immense damage to real victims of the war. Together with the enlightening nature of international law, we can presuppose that the international society and law today have reached the stage to be able to realize the principles of risk liability. They can also decipher who has responsibility in the relationship between and the interpretation of, the international humanitarian law and the international law of human rights. Certainly, its immediate execution is difficult from the viewpoint of the institutional or systematic aspect. However, if we could create and build up the suppression effect in the ideological aspect, we could come up with an idea which is not entirely meaningless. The researches on LAWS and on the relationships between international humanitarian law and the international law of human rights have accumulated in the recent study of international law in Japan. In particular, the academic trend is that the international law of human rights and its principles must be applied in cases of armed conflicts, especially for the plight of the victims. Both studies are, however, at present independent of each other. This essay is written on the basis of such trend. Hence, the problems caused by LAWS do not stay in the conventional field of laws on armed conflicts, but could cover a wider scope of human rights violations. As a result, to predict that the international law of human rights is applied to those problems must certainly have the power to somehow supress the real usage of LAWS in the future. The meaning of this essay exists to forward such point.

\section{Nanomachine and International Regulations}

A nanomachine has been described as a lethal autonomous weapon. There are many types of nanomachines, and the newest type has a flexible constitution mainly including proteins, specifically 20 amino acids, and this type of nanomachine is not strictly regulated. In other words, once the new artificial virus that is based on an artificial array of amino acids is created, it invades the human body or fundamental environments and starts acting in accordance with the program stimulations. In addition, in the case of a nanomachine made by carbon and silicon, there is a possibility of self-propagation that results in a "gray goo." In instances where these nanomachines are used as weapons, the method of separating real situations and selecting and applying international rules from the pool of international human rights law and international humanitarian law will not be effective. For example, considering on the issue of COVID-19, if it is an artificial nanomachine, it would have the possibility completely erasing the human race from the face of the earth. Therefore, it's suggested that the issue of the Lethal Autonomous Weapons Systems (LAWS) should also be expanded to cover the study of nanomachines in the future.

Nano means 10-9 and a nanometer is a one-billionth meter. Nanomachine means an extremely microscopic machine that is the same as a micro-virus $(10 \mathrm{~nm} \sim 100 \mathrm{~nm})$ and smaller than bacterium or cells. Therefore, the term nanomachine attaches greater importance to mechanical actions. On the other hand, there is nanotechnology. Nanotechnology means a technology that doesn’t include mechanical actions such as circuit- formation. Both nanotechnology and nanomachines applied different concepts traditionally; however, developments in natural sciences or scientific techniques have been showing a tendency of unifying both concepts, especially the non-metallic system, which is the key element in a 
nanomachine.

There are three treaties applicable to a nanomachine, even though the concept of a nanomachine is not defined. They include the following:

First, the Convention on the Prohibition of the Development, Production and Stockpiling of Bacteriological (Biological) and Toxin Weapons and on Their Destruction (entered into force in 1975).

Second, the Convention on the Prohibition of the Development, Production and Stockpiling and Use of Chemical Weapons on Their Destruction (entered into force in1997).

Third, the United Nations Framework Convention on Climate Change (entered into force in 1994).

The article 1 of the first convention provides:

Each State Party to this Convention undertakes to never, in any circumstances, develop, produce, stockpile, or otherwise acquire or retain:

(1) Microbial or other biological agents or toxins, whatever their origin or method of production, of types and in quantities that have no justification for prophylactic, protective, or other peaceful purposes;

(2) Weapons, equipment, or means of delivery designed to use such agents or toxins for hostile purposes or in armed conflict.

The article 2 of the second convention provides:

Paragraph 1: "Chemical Weapons" means the following, together or separately: (a) Toxic chemicals and their precursors, except where intended for purposes not prohibited under this Convention, as long as the types and quantities are consistent with such purposes;

Praragraph 2: "Toxic Chemical" means: Any chemical which through its chemical action on life processes can cause death, temporary incapacitation, or permanent harm to humans or animals. This includes all such chemicals, regardless of their origin or of their method of production and regardless of whether they are produced in facilities, in munitions, or elsewhere. (For the purpose of implementing this Convention, toxic chemicals that have been identified for the application of verification measures are listed in Schedules contained in the Annex on Chemicals.)

Paragraph 3: "Precursor" means any chemical reactant that takes part at any stage of production by whatever method of a toxic chemical. This includes any key component of a binary or multicomponent chemical system.

Article 4 of the third convention provides:

Pragraph 1: All Parties, taking into account their common but differentiated responsibilities and their specific national and regional development priorities, objectives, and circumstances, shall: (d) Promote sustainable management and promote and cooperate in the conservation and enhancement, as appropriate, of sinks and reservoirs of all greenhouse gases not controlled by the Montreal Protocol, including biomass, forests and oceans as well as other terrestrial, coastal, and marine ecosystems;

(e) Cooperate in preparing for adaptation to the impacts of climate change; develop and 
elaborate appropriate and integrated plans for coastal zone management, water resources and agriculture, and for the protection and rehabilitation of areas, particularly in Africa, affected by drought and desertification, as well as floods.

From the provisions above, one would wonder whether each convention is applicable to a nanomachine. However, it is difficult to determine this, especially if a real incident doesn't occur. An autonomous metallic nanomachine may be included in this category of LAWS. A model of this nonmetallic type of nanomachine is an artificial virus that is programmed to take actions and cause some effect automatically under some specific circumstances. Therefore, this type of nanomachine, which is an autonomous system, isn't probably included in this category of LAWS. In case the nanomachine concerned doesn't have toxins or hostile purposes and it doesn't constitute greenhouse gases, it can be difficult to apply the three conventions mentioned above to that type of nanomachine. Since the Martens Clause only applies in situations of armed conflicts, this clause cannot be applied to non-armed conflict situations such as daily life experiences.

There are also certain misconceptions about a nanomachine or nanotechnology and the gray goo. The real fact is that these two are different from movies or scientific novels. There is the law on conservation of mass or energy, which controls the increase of a nanomachine and, as a result, its inexhaustible or eternal increase will not occur. On the other hand, a nanomachine or nanotechnology can turn into a virus. This nanomachine-virus has the ability to directly affect cells or DNA in the body. In sum, a nanomachine or nanotechnology is a non-metallic autonomous system that becomes an artificial virus, and there are no international laws that regulate this technology.

\section{Conclusion}

Regarding LAWS, its regulation expressly specifies the space and time situation within which they should be used. Some laws are meant to be used in spaces where there is armed conflict and others in situations of war or armed conflicts. The tendency of the responsibility, including liability and accountability, is clearly defined and placed on a person or a state that implements LAWS. However, when the damage and loss of civilian lives occur due to the legitimate acts of LAWS, who should be held responsible for such losses and suffering? Lawful acts of LAWS affect the daily lives of people, who end up wandering and becoming refugees. The existing international law exonerates a state that used weapons lawfully. The integration principle, however, is now beginning to appreciate the relationship between international human rights law and international humanitarian law. From its perspective, the responsibility of the state using LAWS is limited to the time and space of armed conflicts under LAWS. This is an important issue on LAWS that future amendments should consider.

The most important issue when it comes to nanomachines is the autonomous non- metallic system, which eventually becomes an artificial virus. This issue influences the type of applicable laws, depending on the legal situation (i.e., whether there is peace or war). This implies that that the applicable laws will lose their effectiveness if neither situation exists.

Currently, there's no law that specifically governs nanomachines.

When meditating upon the social background on which the issues mentioned above occur, the international community, including the United Nations, was mainly guided by the Cold War and the North-South problem. In the field of academia, some theories in realism, idealism, and structuralism 
were developed to analyze and explain international relations from the perspective of those social backgrounds. Even after the Cold War, the scramble to take over power in some countries is still on and local armed conflicts are still witnessed. These conflicts cannot be explained by past theories. For instance, TANAKA Akihiko, who published Atarashii Chusei (The New Meddle Ages) ${ }^{45}$, propounds a theory that uses different time stages. Based on this theory, the traditional way of classifying and aligning international relations to conditions of peace and armed conflicts loses its effectiveness, and we have not found a substitute for traditional theories yet. Amid this situation, we are confronted with the issue of nanomachine-virus.

Generally, we must deal with some issues effectively and separately depending on the timeframe and space within which they occur. Therefore, the theory of autopoiesis may be useful in analyzing and explaining some issues for now. This theory revolves around non- intentional relationships among independent existences. If the framework made by traditional theories loses the useful effectiveness, the explanation of internal relationships by the theory of autopoiesis will probably be useful and effective. This theory can be applied in explaining the international community from the present time to the near future. Therefore, the relations between international law and the most advanced scientific techniques can be analyzed and explained by studies of mutual influences among each subject of research in the future.

45 Cf., Akihiko TANAKA, Atarashii Chusei, Nihon Keizai Shinbun-sha, 2003. 